\title{
The freshwater crabs of Ethiopia, northeastern Africa, with the description of a new Potamonautes cave species (Brachyura: Potamonautidae)
}

\author{
Neil Cumberlidge ${ }^{1,3}$, Paul F. Clark ${ }^{2}$ \\ ${ }^{1}$ Department of Biology, Northern Michigan University, Marquette, Michigan 49855, USA \\ ${ }^{2}$ Department of Zoology, The Natural History Museum, Cromwell Road, London, SW7 5BD, UK \\ ${ }^{3}$ E-mail: ncumberl@nmu.edu
}

Key words: Potamonautes kundudo sp. nov., Potamonautes antheus, Potamonautes ignestii, freshwater crabs, Mount Kundudo, Potamoidea

\begin{abstract}
A recent collection of freshwater potamonautid crabs from a newly-explored cave in Ethiopia included a new species of Potamonautes MacLeay, 1838, which is described. The new species is associated with caves but is not troglobitic because it has no special morphological adaptations for life in caves typical of other species of cave-dwelling freshwater crabs. The taxonomic status and biogeographic affinities of other Ethiopian freshwater crab species are discussed. Potamonautes antheus (Colosi, 1920) and P. ignestii (Parisi, 1923) are recognized as valid species, and a key to the species of the country is included. The addition of $P$. kundudo sp. nov. and the recognition of two previously suppressed taxa raises to six the number of freshwater crab taxa known to occur in Ethiopia.
\end{abstract}

\section{Contents}

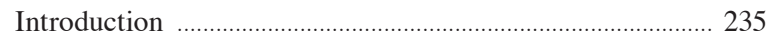

Material and methods ……........................................................... 237

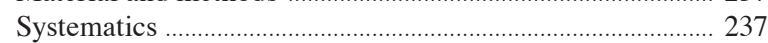

Potamonautes kundudo sp. nov. ...................................... 237

Potamonautes antheus (Colosi, 1920) .............................. 241

Potamonautes berardi (Audouin, 1826) ........................... 243

Potamonautes holthuisi Cumberlidge and Meyer, 2010245

Potamonautes ignestii (Parisi, 1923) ............................... 245

Potamonautes niloticus (H. Milne Edwards, 1837) ....... 247

Biogeography ................................................................... 248

Acknowledgements ................................................................. 249

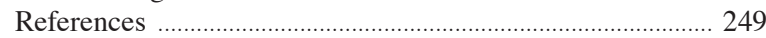

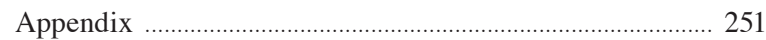

\section{Introduction}

This work reports on the discovery of a new species of potamonautid freshwater crab from Ethiopia which is described. The new species of freshwater crab was collected from a resurgent spring flowing inside and outside of a cave on Mount Kundudo (2,499 m asl) in the Ahmar Mountains in the Oromia Region of east- ern Ethiopia. The specimens were entrusted for study to the second author by Italian speleologists Prof. Marco Viganó and Dr. Danilo Baratelli who were the first to explore the newly discovered cave. These specimens are described and assigned to the Afrotropical freshwater crab family Potamonautidae Bott, 1970 , based on a novel combination of somatic characters (Figs. 1-4) including the gonopods, carapace, and sternum of the holotype, an adult male. The new discovery raises to six the number of valid species of Ethiopian freshwater crabs (Table 1; Cumberlidge, 2009; Cumberlidge and Meyer, 2010). These species are Potamonautes antheus (Colosi, 1920), P. berardi (Audouin, 1826), P. holthuisi Cumberlidge and Meyer, 2010, P. ignestii (Parisi, 1923), P. niloticus (H. Milne Edwards, 1837), and the new species which is described here.

This treatment of the freshwater crabs of Ethiopia differs radically from that of Bott (1955) who recognized four species from this country which he called Potamonautes (Rotundopotamonautes) berardi berardi, and Potamonautes (Acanthothelphusa) niloticus, P. (R.) aloysiisabaudiae (Nobili, 1906), and P. (R.) didieri (Rathbun, 1904) (Table 1). Bott (1955) also included three other taxa Potamon (Geotelphusa) ignestii, Potamon (Potamonautes) lindblomi Colosi, 1924, and Potamon (Geothelphusa) neumanni var. laetabilis De Man, 1914, as either subspecies or junior synonyms of his Ethiopian species. However, recent studies indicate that only two out of four of Bott's (1955) species (Potamonautes berardi and P. niloticus) are now known to actually occur in Ethiopia. For example, $P$. aloysiisabaudiae is found only in the region of the Ruwenzori Mountains in western Uganda and eastern D. R. Congo, and there are no confirmed records of this species within hundreds of kilometres of Ethiopia (Corace et al., 2001; Cumberlidge, 2009). Similarly, P. didieri is from the Kibali River in the D. R. 
Congo, but both Chace (1942) and Bott (1955) incorrectly reported that this locality was in Ethiopia; however, this is doubtful because there are still no reliable records of the presence of $P$. didieri outside of the Congo basin (Cumberlidge, 2009).

In the present study the Ethiopian Potamonautes MacLeay, 1838, are reconsidered. Two previously suppressed species, $P$. antheus and $P$. ignestii, are resurrected and recognized as valid. Previously $P$. antheus was treated by Bott (1955) as a junior synonym of $P$. aloyiisabaudiae, and $P$. ignestii as a subspecies of $P$. berardi. Their revised status is based on the examination of a series of unpublished specimens collected in Ethiopia between 1960 and 1980 (Table 1). As a consequence, adult males of $P$. antheus and P. ignestii are rediagnosed, redescribed, and illustrated here because of the longstanding taxonomic confusion surrounding these two taxa. Furthermore, two other freshwater crabs, $P$. aloysiisabaudiae and $P$. didieri, previously included in a list of species for Ethiopia compiled by Bott (1955) are not recognized here as members of the fauna of that country (Table 1). All of the freshwater

Table 1. Present identifications of freshwater crab taxa from Ethiopia compared with those of the last major revision by Bott (1955). DD $=$ data deficient, $\mathrm{LC}=$ least concern, $\mathrm{VU}=$ vulnerable, $\mathrm{NA}=$ not assessed.

\begin{tabular}{llll}
\hline Taxon & Identification in Bott (1955) & $\begin{array}{l}\text { Country in } \\
\text { present work }\end{array}$ & $\begin{array}{l}\text { Identification in } \\
\text { present work }\end{array}$ \\
\hline $\begin{array}{l}\text { Potamon (Potamonautes) } \\
\text { aloysiisabaudiae }\end{array}$ & $\begin{array}{l}\text { Potamonautes } \\
\text { (Rotundopotamonautes) } \\
\text { aloysiisabaudiae }\end{array}$ & $\begin{array}{l}\text { Uganda, } \\
\text { D. R. Congo } \\
\text { status } \\
\text { (not Ethiopia) }\end{array}$ & $\begin{array}{l}\text { Potamonautes } \\
\text { aloysiisabaudiae }\end{array}$ \\
\hline $\begin{array}{l}\text { Potamon } \\
\text { (Geothelphusa) } \\
\text { antheus Colosi, } 1920\end{array}$ & $\begin{array}{l}\text { junior synonym of Potamonautes } \\
\text { (Rotundopotamonautes) } \\
\text { aloysiisabaudiae }\end{array}$ & Ethiopia \\
\hline
\end{tabular}

\begin{tabular}{|c|c|c|c|c|}
\hline $\begin{array}{l}\text { Thelphusa berardi } \\
\text { Audouin, } 1826\end{array}$ & $\begin{array}{l}\text { Potamonautes } \\
\text { (Rotundopotamonautes) } \\
\text { berardi berardi }\end{array}$ & $\begin{array}{l}\text { Ethiopia, Egypt, Sudan, } \\
\text { Southern Sudan, Uganda, } \\
\text { Tanzania, Rwanda }\end{array}$ & Potamonautes berardi & $\mathrm{LC}$ \\
\hline $\begin{array}{l}\text { Potamon } \\
\text { (Potamonautes) didieri } \\
\text { Rathbun, } 1904\end{array}$ & $\begin{array}{l}\text { Potamonautes } \\
\text { (Rotundopotamonautes) didieri }\end{array}$ & $\begin{array}{l}\text { D. R. Congo } \\
\text { (not Ethiopia) }\end{array}$ & Potamonautes didieri & $\mathrm{DD}$ \\
\hline $\begin{array}{l}\text { Potamon } \\
\text { (Geotelphusa) ignestii } \\
\text { Parisi, } 1923\end{array}$ & $\begin{array}{l}\text { Potamonautes } \\
\text { (Rotundopotamonautes) } \\
\text { berardi ignestii }\end{array}$ & Ethiopia & Potamonautes ignestii & $\begin{array}{l}\text { VU, B1ab(i); } \\
\text { D2 }\end{array}$ \\
\hline $\begin{array}{l}\text { Potamonautes kundudo } \\
\text { sp. nov. }\end{array}$ & $\mathrm{n} / \mathrm{a}$ & Ethiopia & Potamonautes kundudo & NA \\
\hline $\begin{array}{l}\text { Potamonautes holthuisi } \\
\text { Cumberlidge \& Meyer, } \\
2010\end{array}$ & $\mathrm{n} / \mathrm{a}$ & Ethiopia & Potamonautes holthuisi & NA \\
\hline $\begin{array}{l}\text { Potamon (Geothelphusa) } \\
\text { neumanni var. laetabilis } \\
\text { De Man, } 1914\end{array}$ & $\begin{array}{l}\text { junior synonym of Potamonautes } \\
\text { (Rotundopotamonautes) didieri }\end{array}$ & Ethiopia & $\begin{array}{l}\text { Uncertain taxon, not a } \\
\text { junior synonym of } \\
P \text {. didieri }\end{array}$ & NA \\
\hline $\begin{array}{l}\text { Potamon (Potamonautes) } \\
\text { lindblomi Colosi, } 1924\end{array}$ & $\begin{array}{l}\text { junior synonym of Potamonautes } \\
\text { (Rotundopotamonautes) } \\
\text { berardi ignestii }\end{array}$ & Kenya (not Ethiopia) & Potamonautes lindblomi & NA \\
\hline $\begin{array}{l}\text { Telpheusa nilotica } \\
\text { H. Milne Edwards, } 1837\end{array}$ & $\begin{array}{l}\text { Potamonautes } \\
\text { (Acanthopotamonautes) niloticus }\end{array}$ & $\begin{array}{l}\text { Ethiopia, Egypt, Sudan, } \\
\text { Southern Sudan, Uganda, } \\
\text { Kenya, Rwanda }\end{array}$ & Potamonautes niloticus & $\mathrm{LC}$ \\
\hline
\end{tabular}


crab taxa that have been reported to occur in Ethiopia are evaluated (Table 1), including the most recent addition, $P$. holthuisi from the Omo-Turkana basin in the southwest of the country (Cumberlidge and Meyer, 2010). An identification key to the Ethiopian species of the freshwater crabs is provided (Appendix).

\section{Material and methods}

Specimens are deposited in the Natural History Museum, London, UK (NHM); the Department of Biology, Northern Michigan University, Marquette, MI, USA (NMU); the Museo di Storia Naturale di Milano, Italy (MSNM); the United States National Museum of Natural History, Smithsonian Institution, Washington DC, USA (USNM); and the Zoologische Staatsammlung, Munich, Germany (ZSM). All measurements were made with digital calipers and are in millimetres. Abbreviations used: a1-a6, abdominal somites 1-6; a7, telson of the abdomen; asl, above sea level; cw, distance across the carapace at the widest point; ch, carapace height, the maximum height of the cephalothorax; $\mathrm{cl}$, carapace length measured from the frontal margin to the posterior margin; coll., collected by; fw, front width measured along the anterior margin; e, thoracic episternite; G1, first gonopod (= first pleopod of male); G2, second gonopod (= second pleopod of male); juv., juveniles; ovig., ovigerous; p1-p5, pereiopods $1-5 ; \mathrm{s}$, thoracic sternite; s1/s2, s2/s3, s3/s4, sternal sutures between adjacent thoracic sternites; s4/e4, s5/ e5, s6/e6, s7/e7, episternal sutures between adjacent thoracic sternites and episternites. The terminology is adapted from Cumberlidge (1999) and the higher classification used follows that of $\mathrm{Ng}$ et al. (2008). Line drawings were prepared using a Leica MZ 16 binocular microscope and the habitus photographs were taken with a digital camera. Post processing was done using Adobe Photoshop 7.0.

\section{Systematics}

\section{Potamonautes kundudo sp. nov.}

Figs. 1-4, 7E, Tables 1-2

\section{Type material and type locality}

Ethiopia: Holotype, adult ${ }^{\top}, \mathrm{cw} 24.2$, cl 17.5, ch 7.8, fw $7.8 \mathrm{~mm}$ (NHM 2012.1033), from a karstic spring flowing out of the Gursum Pearl cave (Biyyu Negheya) on Mount Kundudo at 2,500 m asl, near Dire Dawa, Gur- sum Province (woreda), East Hararge Zone, Oromia Region (09 $\left.26^{\prime} \mathrm{N}, 42^{\circ} 20^{\prime} \mathrm{E}\right)$, coll. Prof. Marco Viganò, presented by Danilo Baratelli, 4 Apr. 2010. Paratypes, adult + , cw 26.1, cl 19.2, ch 8.8, fw 8.6 mm (NHM 2012.1034); adult 0 cw 22.9, cl 16.2, ch 7.45, fw 6.3 mm (MSNM 2436), adult $\delta \mathrm{cw} 22.8$, cl 16.5, ch 7.8, fw $7.5 \mathrm{~mm}$ (MSNM 2437), adult ôे cw $22 \mathrm{~mm}$, damaged (MSNM 2438); subadult $\delta \mathrm{cw} 18.2 \mathrm{~mm}$, subadult $\delta^{\dagger}$ cw $14.6 \mathrm{~mm}$, subadult ô $\mathrm{cw} 14.5 \mathrm{~mm}$, juv. ô $\mathrm{cw} 12.3$ $\mathrm{mm}$, subadult $q \mathrm{cw} 18.4 \mathrm{~mm}$, subadult $q \mathrm{cw} 15.0 \mathrm{~mm}$, (NHM 2012.1035-1040); all paratypes same locality data as holotype. The first specimen ( + ) was collected from a locality inside the cave by Prof. Marco Viganò and Giampaolo Rivolta, 13 Feb. 2009, but was not preserved.

\section{Diagnosis}

Carapace medium height (ch/fw 1.0). Exorbital, epibranchial teeth reduced to granules, postfrontal crest incomplete, faint in middle, lateral ends well defined, meeting epibranchial teeth; anterolateral margin posterior to epibranchial tooth granular; carapace sidewall vertical suture faint, incomplete, not meeting anterolateral margin. Ischium of third maxilliped lacking vertical groove. Sternal suture s3/s4 complete, Ushaped, deep at edges, faint in middle, almost meeting thick, raised anterior margin of sternoabdominal cavity. Inferior margins of merus of cheliped granular, distal meral tooth pointed; first carpal tooth medium sized, pointed, second carpal tooth reduced to large granule. G1 terminal article straight basally, midsection and tip curving outward, midsection not widened, tip evenly tapering, not upturned.

\section{Description}

Based on adult male holotype (cw $24.2 \mathrm{~mm}$ ). Carapace oval, wide (cw/fw 3.1), high (ch/fw 1.0); surface smooth; cardiac, urogastric grooves faint; cervical grooves short, faint; transverse branchial grooves faint (Fig. 1c). Eyestalks normal length (not shortened), corneas normal size (not reduced). Front wide (fw/cw 0.32), deflexed (Fig. 1c). Postfrontal crest incomplete, faint in middle, lateral ends well defined, meeting epibranchial teeth; postorbital, epigastric crests faint (Fig. 1c). Exorbital, epibranchial teeth both reduced to single granules, continuous with granulated anterolateral margin, latter continuous with posterolateral margin; carapace sidewalls smooth, divided into three parts by two sutures, vertical suture faint and incomplete, not meeting anterolateral margin; suborbital, subhepatic, pterygostomial regions of carapace sidewalls completely smooth 

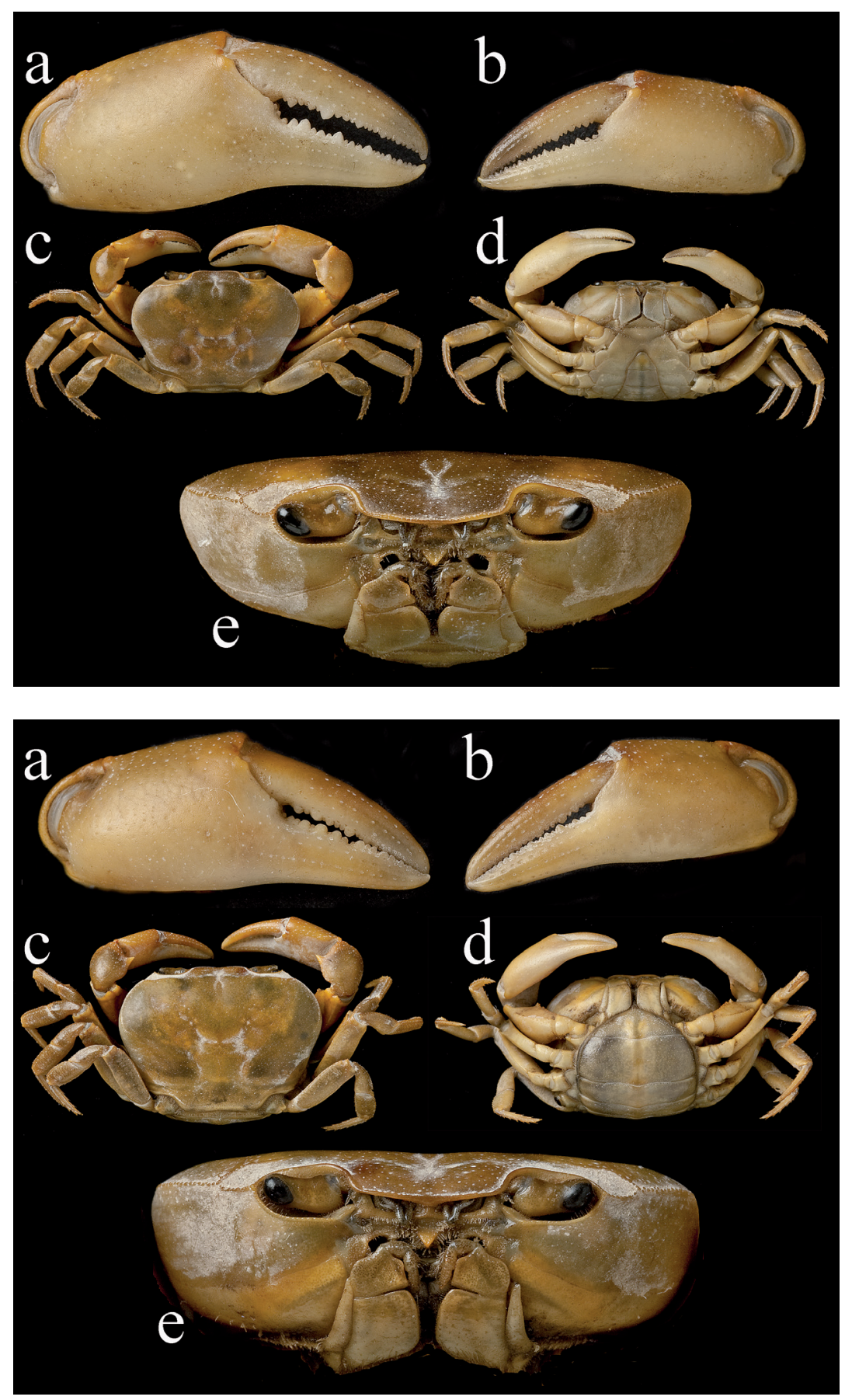

Fig. 1. Potamonautes kundudo sp. nov. Holotype, adult male, cw $24.2 \mathrm{~mm}$, from Gursum Pearl cave on Mount Kundudo, Ethiopia (NHM 2012. 1033). Frontal view: a. right cheliped, b. left cheliped. Whole animal: c. dorsal view; d. ventral view; e. carapace frontal view. Photograph Phil Crabb, NHM Photographic Unit.

Fig. 2. Potamonautes kundudo sp. nov. Paratype, adult female, cw $26.1 \mathrm{~mm}$, from Gursum Pearl cave on Mount Kundudo, Ethiopia (NHM 2012.1034). Frontal view: a. right cheliped, b. left cheliped. Whole animal: c. dorsal view; d. ventral view; e. carapace frontal view. Photograph Phil Crabb, NHM Photographic Unit.
(Fig. 1e). Mandibular palp two-segmented, terminal article simple, setose; epistomial tooth triangular, deflexed, edges smooth. Third maxillipeds filling entire oral field, except for transversely oval respiratory openings at superior lateral corners; ischium of third maxilliped lacking vertical groove; exopod of third maxilliped reaching to lower half of merus, terminal segment flagellum-like (Fig. 1e).

Sternal suture s1/s2 absent; s2/s3 deep, complete, running horizontally across sternum; s3/s4 U-shaped, deep at edges, faint in middle, almost meeting thick, raised anterior margin of sternoabdominal cavity; 
episternal sutures s4/e4, s5/e5, s6/e6, s7/e7, all faint, incomplete (Fig. 1d). Abdomen slim, outline triangular, tapered, widest at base, telson outline forming straight-sided triangle with broad base, rounded apex; s6/s7 meeting abdomen at a5/a6; s5/s6 meeting a6 one half of segment length from a6/a5 (Fig. 1d). G1 terminal article straight basally, midsection, tip curving outward, midsection not widened, tip evenly tapering, not upturned (Fig. 3). G2 terminal article flagellumlike, less than half as long as subterminal segment. Subterminal segments of G1, G2 equal in length (Fig. 4). Dactylus of major cheliped slender, slightly arched, closed fingers enclosing long narrow interspace; upper margin of dactylus of cheliped smooth; fixed finger of propodus of major (right) cheliped slender with two distinct, large teeth in proximal region followed by series of smaller teeth; lower margin of propodus slightly indented (Fig. 1a-b); first carpal tooth distinct, pointed; second carpal tooth less than half size of first carpal tooth, pointed, followed by several small granules; distal meral tooth small, pointed; ventral margins of merus of cheliped lined by series of large granules; superior surface of merus smooth (Fig. 1c-d). Walking legs (p2-p5) normal length (neither elongated nor shortened); p3 longest limb, p5 shortest limb; dactyli of p2-p5 tapering to point, each bearing four rows of downward-pointing short, sharp spines (Fig. 1c). Col- our of dorsal carapace and legs uniformly dark brownpurple.

\section{Etymology}

This species is named for Mount Kundudo in Ethiopia. The name is used as a noun in apposition.

\section{Size}

A small-sized species, the largest known specimen is the adult female paratype, cw $26.1 \mathrm{~mm}$.

\section{Remarks}

Potamonautes kundudo sp. nov. is distinguished from the other species found in Ethiopia (P. niloticus, P. berardi, $P$. antheus, $P$. ignestii, and $P$. holthuisi) by its slim G1 terminal article that is straight basally with an outward-curving midsection and tip, a midsection that is slim, not widened, and a tip that tapers evenly and is not upturned (Table 2, and the identification key to the species below).

Potamonautes kundudo sp. nov. is most similar to $P$. holthuisi because these two medium-sized species share the following characters: a weak postfrontal crest, a small and pointed first carpal tooth on the P1 carpus, a small pointed distal meral tooth on the P1 merus, and a slim G1 terminal article that is not widened in the midsection. Potamonautes kundudo sp.

Table 2. Comparison of the morphological characters of the six freshwater Potamonautes species found in Ethiopia. Abbreviations are provided in material and methods and taxonomic authorities in the systematics section.

\begin{tabular}{|c|c|c|c|c|c|c|}
\hline Character & P. antheus & P. berardi & P. holthuisi & P. kundudo sp. nov. & P.ignestii & P. niloticus \\
\hline Anterolateral margin & smooth & smooth & smooth & granular & granular, raised & several teeth \\
\hline Exorbital tooth & granule & granule & granule & granule & granule & large, pointed \\
\hline Epibranchial tooth & granule & granule & granule & granule & granule & large, pointed \\
\hline $\begin{array}{l}\text { Vertical suture on } \\
\text { sidewall meeting } \\
\text { anterolateral margin }\end{array}$ & no & yes & yes & no & yes & no \\
\hline Postfrontal crest & $\begin{array}{l}\text { incomplete, } \\
\text { faint in middle }\end{array}$ & $\begin{array}{l}\text { incomplete, } \\
\text { faint in middle }\end{array}$ & $\begin{array}{l}\text { incomplete, } \\
\text { faint in middle }\end{array}$ & $\begin{array}{l}\text { incomplete, } \\
\text { faint in middle }\end{array}$ & $\begin{array}{l}\text { complete, } \\
\text { distinct }\end{array}$ & $\begin{array}{l}\text { complete, } \\
\text { distinct }\end{array}$ \\
\hline $\begin{array}{l}\text { Third maxilliped } \\
\text { ischial groove }\end{array}$ & faint/ absent & faint/ absent & faint/absent & faint/absent & faint/absent & faint/absent \\
\hline $\begin{array}{l}\text { P1 carpus: } \\
\text { 1st carpal tooth }\end{array}$ & large, pointed & small, pointed & small, pointed & small, pointed & small, pointed & large, pointed \\
\hline $\begin{array}{l}\text { P1 merus: distal } \\
\text { meral tooth }\end{array}$ & granule & large, pointed & small, pointed & small, pointed & large, pointed & large, pointed \\
\hline $\begin{array}{l}\text { GO1 terminal } \\
\text { article tip }\end{array}$ & upturned & upturned & upturned & straight & upturned & upturned \\
\hline $\begin{array}{l}\text { GO1 terminal } \\
\text { article mid-section }\end{array}$ & widened & $\begin{array}{l}\text { slim, not } \\
\text { widened }\end{array}$ & $\begin{array}{l}\text { slim, not } \\
\text { widened }\end{array}$ & $\begin{array}{l}\text { slim, not } \\
\text { widened }\end{array}$ & widened & $\begin{array}{l}\text { slim, not } \\
\text { widened }\end{array}$ \\
\hline Adult size range $(\mathrm{cw})$ & $55-66 \mathrm{~mm}$ & $22-31 \mathrm{~mm}$ & $26.1 \mathrm{~mm}$ & $22-26 \mathrm{~mm}$ & $40 \mathrm{~mm}$ & $54-63 \mathrm{~mm}$ \\
\hline Adult body size & large & small & medium & small & medium & large \\
\hline
\end{tabular}




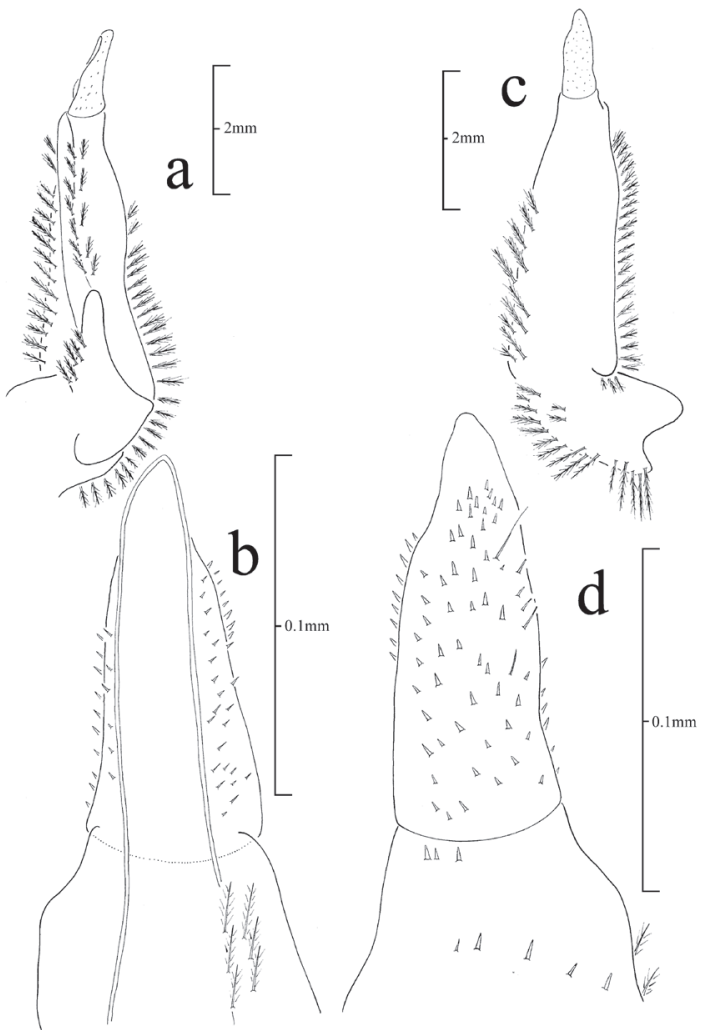

Fig. 3. Potamonautes kundudo sp. nov. Holotype, adult male, cw $24.2 \mathrm{~mm}$, from Gursum Pearl cave on Mount Kundudo, Ethiopia (NHM 2012. 1033). Left G1. Ventral view: a. entire; b. distal tip. Dorsal view: c. entire; d. distal tip.

nov. can be distinguished from $P$. holthuisi by the anterolateral margin (which is granular in P. kundudo sp. nov. and smooth in $P$. holthuisi) and by the vertical suture on the carapace sidewall (which does not meet the anterolateral margin in P. kundudo sp. nov. but does meet this margin in P. holthuisi) (Fig. 1e; Cumberlidge and Meyer, 2010).

Potamonautes kundudo sp. nov. is distinguished from the remaining four Ethiopian species as follows. The new species is distinguished from P. niloticus by the postfrontal crest (which is weak and incomplete in $P$. kundudo sp. nov., but strongly defined and complete in P. niloticus, by the anterolateral margin (which is granular in $P$. kundudo sp. nov., but distinctly toothed in P. niloticus), and by the exorbital and epibranchial teeth (which are both reduced to small granules in $P$. kundudo sp. nov., but both are large and pointed in $P$. niloticus) (see Capart, 1954; Cumberlidge and Clark, 2010a). Potamonautes kundudo sp. nov. is distinguished

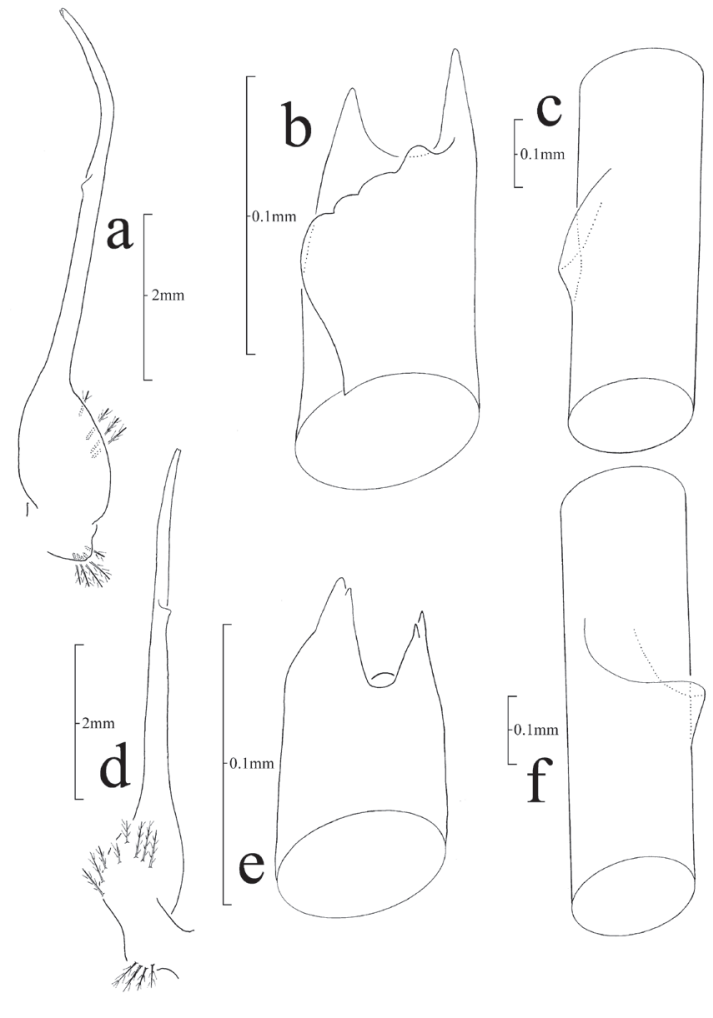

Fig. 4. Potamonautes kundudo sp. nov. Holotype, adult male, cw $24.2 \mathrm{~mm}$, from Gursum Pearl cave on Mount Kundudo, Ethiopia (NHM 2012. 1033). Left G2. Ventral view: a. entire, b. distal tip, c. medial section. Dorsal view: d. entire, e. distal tip, f. medial section.

from P. ignestii by the postfrontal crest (which is weak and incomplete in P. kundudo sp. nov., but strongly defined and complete in P. ignestii), and by the carapace sidewall vertical suture (which does not meet the anterolateral margin in P. kundudo sp. nov., but does meet this margin in P. ignestii) (Figs. 1d-e; 6; Cumberlidge, 1997; Bott, 1955). Potamonautes kundudo sp. nov. is distinguished from $P$. antheus by the adult body size range (which is above cw $26 \mathrm{~mm}$ in $P$. kundudo sp. nov., but above cw $55 \mathrm{~mm}$ in P. antheus), by the anterolateral margin (which is granular in P. kundudo sp. nov., but smooth in P. antheus) and by the carapace sidewall vertical suture (which does not meet the anterolateral margin in P. kundudo sp. nov., but does meet this margin in $P$. antheus), and by the midsection of the G1 terminal article (which is slim and not widened in P. kundudo sp. nov., but extremely wide in $P$. antheus). Finally, the new species is distinguished from $P$. berardi by the adult body size range (which is between $\mathrm{cw} 22-26 \mathrm{~mm}$ in 
adult $P$. kundudo sp. nov., but $\mathrm{cw} 22-31 \mathrm{~mm}$ in adult $P$. berardi), by the anterolateral margin (which is granular in P. kundudo sp. nov., but smooth in P. berardi), and by the carapace sidewall vertical suture (which does not meet the anterolateral margin in $P$. kundudo sp. nov., but does meet this margin in $P$. berardi).

\section{Ecology}

The new species was found during an expedition to newly explored caves on Mount Kundudo, Ethiopia in February 2009 by Italian speleologists from CAI Gallarate, Varese, Italy. The first specimen (a female) was encountered from the stream inside the cave by Prof. Marco Viganò and Giampaolo Rivolta, on 13 February 2009 , but was only photographed and was not preserved. The second series of specimens (reported on here) were captured a year later from the cave outlet stream close to the cave entrance. This stream then flows southward through a highly disturbed forested area that is drained by perennial rivers such as the Hariro, Goro Obole, Bombas, Ejerti, and Agemsa that are tributaries of the Shebele River that flow southeast through the Somali region of Ethiopia, eventually passing through Somalia before emptying into the Indian Ocean. Crabs were observed to move between the cave and the outlet spring outside, and it is likely that there is more food (plant material and detritus) available outside the cave.

Specialised troglobitic cave-dwelling freshwater crabs are unknown in continental Africa, and although the new species lives in a cave, it has no special morphological adaptations typical of other species of troglobitic freshwater crabs found elsewhere in the world. For example, the cave crab Stygothelphusa bidiensis (Lanchester, 1900) (Gecarcinucidae) from Sarawak, Malaysia, has extremely elongated pereiopods, an overall pale coloration, and eyestalks and corneas that are distinctly reduced $(\mathrm{Ng}, 1989)$. Potamonautes kundudo sp. nov. is therefore best described as a species that is associated with caves rather than troglobitic because it is found both inside and outside of caves, its pereiopods are not elongated, it is a uniformly dark brown purple colour, and its eyestalks and corneas are both of normal size.

\section{Distribution}

Potamonautes kundudo sp. nov. is endemic to Ethiopia and is known from a single locality, a spring inside and outside the Biyyu Negeya spring cave in Mount Kundudo, a flat top mountain located in the highlands of eastern Ethiopia. The technical reference name giv- en to this cave is the Biyyu Negeya spring cave, and it is also known as the Gursum Pearl cave because it is located close to the town of Gursum in the Oromia Region of Ethiopia in the Misraq (East) Hararghe Zone $\left(09^{\circ} 26^{\prime} \mathrm{N}, 42^{\circ} 20^{\prime} \mathrm{E}\right)$.

\section{Potamonautes antheus (Colosi, 1920)}

Figs. 5, 7A, Tables 1-2

Potamon (Geothelphusa) antheus Colosi, 1920: 35.

Potamon (Geothelphusa) anteus - Colosi, 1924: 16-17, pl. 1, fig. 6; fig. 12a, b.

Geothelphusa antheus - Balss, 1929: 351-352, fig. 1.

Potamon antheus - Chace, 1942: 206.

Potamonautes antheus - Ng et al., 2008: 170; Cumberlidge et al., 2009: appendix 1, 19; Cumberlidge and Meyer, 2010: 180, 184, 187, table 1.

\section{Material examined}

Adult ô, cw 64.5 mm, Oromia Region (formerly Kefa Province) Bidaru River, Jimma (=Jima) Area, $09^{\circ} 30^{\prime} \mathrm{N}$, 3802'E, coll. A.W.R. McCrae, 2.9.1968, NMU TRW 1968.12; juv., cw 20 mm, Oromia Region (formerly Kefa Province) Bidaru River, Jimma area, $9^{\circ} 30^{\prime} \mathrm{N}$, 3802'E, coll. A.W.R. McCrae, 1968, NMU TRW 1968.15; Ethiopia: Adult ô, cw 64.5, cl 44, ch 21, fw 17 $\mathrm{mm}$, Oromia Region (formerly Kefa Province) Bidiru River near village of Sokoro, ca. $100 \mathrm{~km}$ northeast of Jimma, 0940’N, 38³1'E, coll. M.L. Schmidt, 1969, NMU TRW 1969.15; juv., cw 17.5 mm, Oromia Region (formerly Kefa Province) Maraua River, $10 \mathrm{~km}$ east of

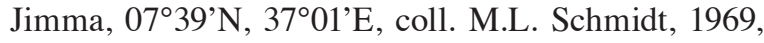
NMU TRW 1969.16; 3 juv., cws 14.5, 19.5, 24.5 mm, Oromia Region (formerly Kefa Province) Atule River, $13 \mathrm{~km}$ east of Jimma, $07^{\circ} 40^{\prime} \mathrm{N}, 36^{\circ} 50^{\prime} \mathrm{E}$, coll. M.L. Schmidt and A.W.R. McCrae, 1969, NMU TRW 1969.17; 2 juv., cws 26, 27.5 mm, Oromia Region (formerly Kefa Province), Yabo River, $21 \mathrm{~km}$ north of Jimma near village of Yabo, $07^{\circ} 45^{\prime} \mathrm{N}, 36^{\circ} 46^{\prime} \mathrm{E}$, coll. M.L. Schmidt and A.W.R. McCrae, 1969, NMU TRW 1969.20; adult 0 , cw 57.5, cl 39.5, ch 18.5, fw $15 \mathrm{~mm}$, subadult ô, cw $50.5 \mathrm{~mm}$, subadult ô $\mathrm{cw} 38 \mathrm{~mm}$, Oromia Region (formerly Kefa Province) Maraua River, $13 \mathrm{~km}$ east of Jimma, $07^{\circ} 39^{\prime} \mathrm{N}, 37^{\circ} 10^{\prime} \mathrm{E}$, coll. M.L. Schmidt and A.W.R McCrae, 1969, NMU TRW 1969.42; adult ô, cw $60.5 \mathrm{~mm}$, adult , cw $56 \mathrm{~mm}$, Oromia Region (formerly Ilubabor Province), Dabama River, 0902'N, 3609'E, coll. K. Uemoto, 1973, NMU TRW 1973.06; juv., cw 33.5 mm, Oromia Region (formerly Kefa Province) Karsa River, Karsa, near Jimma, 


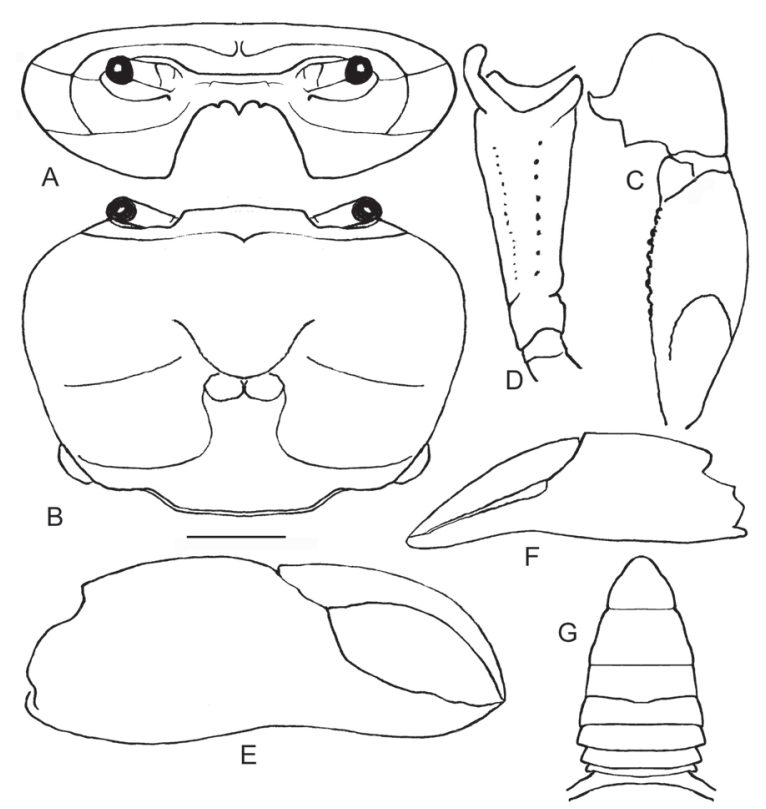

Fig. 5. Potamonautes antheus (Colosi, 1920). Adult male, cw $64.5 \mathrm{~mm}$, from Oromia Region (formerly Kefa Province) Bidaru River, Jimma (=Jima) Area (NMU TRW 1968.12). (A) carapace, frontal view; (B) dorsal view; (C) carpus and merus of cheliped, dorsal view; (D) merus of cheliped, ventral view; (E) right cheliped, frontal view; (F) left cheliped, frontal view; (G) abdomen. Scale bar: $14.3 \mathrm{~mm}$ (A-B, G); $5.8 \mathrm{~mm}(\mathrm{C}-\mathrm{F})$.

0743'N, 3700'E, coll. J.N. Raybould, 1973, NMU TRW 1973.07; adult + , cw $61 \mathrm{~mm}$, Oromia Region (formerly Welega Province), Lor-Chissa River, $08^{\circ} 36^{\prime} \mathrm{N}, 35^{\circ} 44^{\prime}$ E, coll. K. Uemoto, 5 Mar. 1974, NMU TRW 1974.3.05.

\section{Redescription}

Based on adult male (non-type) specimen, cw $64.5 \mathrm{~mm}$ (NMU TRW 1968.12). Postfrontal crest complete, distinct; epigastric, postorbital crests low, fused; postorbital crests extending laterally to meet anterolateral margins; exorbital, epibranchial teeth both reduced to granules; anterolateral margin behind epibranchial tooth smooth; carapace sidewall vertical suture faint, not meeting anterolateral margin; dactylus of major cheliped strongly arched enclosing broad oval interspace when closed; first carpal tooth on carpus of cheliped large, pointed, second carpal tooth weak, low, blunt; ventral margins of merus of pereiopod 1 both smooth; distal meral tooth reduced to low granule; terminal article of G1 straight basally, distinctly widened in midsection by raised dorsal lobe (higher than ven- tral lobe), dorsal lobe distinctly visible on dorsal face; dorsal membrane broad. Large-sized species, adult size range from cw 55 to $\mathrm{cw} 66 \mathrm{~mm}$.

\section{Remarks}

The type specimen is an adult male (cw 56, cl 39, fw 15 $\mathrm{mm})$, collected from 'southwest Ethiopia' sometime before 1920 (Colosi, 1920). The male type was not illustrated in the original description by Colosi (1920), but sketches of the anterior sternum, telson, and G1 terminal article, and a photograph of the dorsal view of the whole animal were provided later by Colosi (1924: 1617, pl. 1, fig. 6; fig. 12a, b). Balss (1929) illustrated the dorsal carapace of a male specimen $(\mathrm{cw} 60 \mathrm{~mm})$ from Doko, Ethiopia, collected by O. Neumann. Despite our best efforts we were unable to locate the type specimens of Potamon (Geothelphusa) antheus Colosi, 1920, but we cannot rule out the possibility that this series may still exist; because of this doubt we have deferred the designation of a neotype in this work. The diagnosis given here is based on a non-type adult male (cw 64.5 $\mathrm{mm}$ ) from Oromia Region (formerly Kefa Province) Bidaru River in the Jimma Area $\left(09^{\circ} 30^{\prime} \mathrm{N}, 38^{\circ} 02^{\prime} \mathrm{E}\right)$ of western Ethiopia collected on 2 September 1968 (NMU TRW 1968.12) (see Fig. 5). This specimen conforms to the published description of the type from southwestern Ethiopia by Colosi (1924) in a number of important characters (e.g., large body size, smooth anterolateral margins, granular exorbital and epibranchial teeth, incomplete postfrontal crest, and a widened midsection of the terminal article of G1). The only major difference between the specimens from southwest Ethiopia described here and the type from southwest Ethiopia illustrated by Colosi (1924), is the form of thoracic sternal suture $s 3 / \mathrm{s} 4$, which is incomplete and represented only by two short notches at the sides of the sternum in the specimens described here, and deep and completely crossing the sternum in the type.

This large species shows some important age-related variations in several morphological characters. For example, the anterolateral margin of large yet still subadult specimens of both genders (with cws of up to 52 $\mathrm{mm}$ ) is distinctly granulated, as are the lateral ends of the postfrontal crest and suborbital margins, whereas all of these margins are smooth in adults (cws 55-65 $\mathrm{mm}$ ). In addition, the anterolateral corners of the carapace surface of juvenile and subadult specimens of both genders have distinct fields of carinae (whereas these areas of the carapace surface are smooth in adults). Further, although the dactylus of the major cheliped of subadult males is arched, it is only half as 
high as that of adult males, and it encloses only a long thin interspace in subadults rather than the wide oval interspace seen in adults. Finally, the major cheliped of subadult males has several large teeth on both of the fingers, whereas the major cheliped of adult males lacks teeth on either of its fingers.

The taxonomy of $P$. antheus has been unstable for over 60 years because Bott (1955) was not able to examine the type specimens of either P. antheus or P. aloysiisabaudiae in his monograph. Nevertheless, that author treated Potamon (Geothelphusa) antheus Colosi, 1920, as a junior synonym of $P$. aloysiisabaudiae Nobili, 1906 (which he called P. (Lobopotamonautes) aloysiisabaudiae). Bott (1955) described this species from Panga $\left(01^{\circ} 52^{\prime} \mathrm{N}, 26^{\circ} 18^{\prime} \mathrm{E}\right)$, Mongbwalu $\left(01^{\circ} 57^{\prime} \mathrm{N}\right.$, $30^{\circ} 1^{\prime} \mathrm{E}$ ), and Bondo Mabe specimens because the type of P. aloysiisabaudiae Nobili, 1906 is unknown. All these localities are from the north of Kisangani in the Orientale Province and lie in the Congo River basin, D. R. Congo. However, it is doubtful that any of these specimens belong to $P$. aloysiisabaudiae (or $P$. antheus). For example, Bott's photographs of ' $P$. aloysiisabaudiae' (Bott, 1955: pl. 18, fig. 2a-d) show a potentially misidentified specimen from Panga, his sketches of the carapace of ' $P$. aloysiisabaudiae' (Bott, 1955: figs. 87-89) are based on specimens from Panga, Mongbwalu, and Bondo Mabe, and his sketches of the G1 of 'P. aloysiisabaudiae' are also based on the specimens from Panga and Mongbwalu (Bott, 1955: figs. 87-89). The presence of $P$. aloysiisabaudiae in Ethiopia is doubtful because the only confirmed records of this species are from the Ruwenzori Mountain region of western Uganda and adjacent D. R. Congo (Corace et al., 2001; Cumberlidge, 2009). Although there is no doubt that $P$. antheus is from Ethiopia, it should be noted that Bott's (1955) view of $P$. antheus as a junior synonym of $P$. aloysiisabaudiae is not in agreement with a number of other authors who considered both $P$. aloysiisabaudiae and $P$. antheus to be valid species (Colosi, 1924; Balss, 1929; Chace, 1942; Ng et al., 2008; Cumberlidge, 2009; Cumberlidge et al., 2009; Cumberlidge and Meyer, 2010). This taxonomic confusion means that the description of the overall morphology of $P$. antheus has not been updated since the descriptions made in the 1920s (Colosi 1920, 1924; Balss, 1929).

\section{Ecology}

No information available.

\section{Distribution}

Potamonautes antheus is endemic to southwest and western Ethiopia (Cumberlidge, 1997, 1998, 2009).
The localities from which this species is known to occur (the Bidaru, Atule, Yabo, Marauwa, and Karsa Rivers) are all in the Oromia Region of Ethiopia and all flow westward into the Nile basin.

\section{Conservation status}

Potamonautes antheus is listed (IUCN, 2009) as least concern (LC) in view of its relatively wide distribution and lack of known widespread long-term threats (Cumberlidge et al., 2009; Table 1).

\section{Potamonautes berardi (Audouin, 1826)}

Fig. 7B, Tables 1-2

Thelphusa Berardi Audouin, 1826: 82, pl. 2, fig. 6, Potamon berardi - Capart, 1954: 827, figs. 4, 31.

Potamonautes (Rotundopotamonautes) berardi berardi - Bott, 1955: 288-289, pl. 23, fig. 5, pl. 23, fig. 1a-d; Monod, 1980: 382-383, pl. V, fig. 28.

Potamonautes berardi - Cumberlidge, 1997: 579; Cumberlidge, 1998: 197-198; Ng et al., 2008: 171; Cumberlidge et al., 2009: appendix 1, 19; Cumberlidge, 2009: 548, 551-557, table 1; Cumberlidge and Meyer, 2010: 180, 184, 187, table 1.

\section{Material examined}

Ethiopia: Adult $\widehat{0}$, cw 23.5, cl 17, ch 8.5, fw $7.5 \mathrm{~mm}, 3$ adult + , cws 24.5, 24.5, $23.5 \mathrm{~mm}$, Southern Nations, Nationalities, and Peoples Region (formerly Sidamo Province) Lintola River, $4 \mathrm{~km}$ north of Soddu, $06^{\circ} 38^{\prime} \mathrm{N}$, 37³7'E, coll. M.L. Schmidt, 5 Oct. 1968, NMU TRW 1969.21; 4 juv., cws 10-12.5 mm, Amhara Region, Debre Marqos, east-central Ethiopia, Misraq Gojjam Zone, $2,446 \mathrm{~m}$ asl, $10^{\circ} 20^{\prime} \mathrm{N}, 37^{\circ} 43^{\prime} \mathrm{E}$, NHM 1960.12.21.1-4; adult + , cw 20.5 mm, Amhara Region, Debre Marqos, east-central Ethiopia, Misraq Gojjam Zone, 2,446 $\mathrm{m}$ asl, $10^{\circ} 20^{\prime} \mathrm{N}, 37^{\circ} 43^{\prime} \mathrm{E}$, NHM 1960.12.21.1; stream at Marefia, $10 \mathrm{~km}$ northeast of Ancober, $09^{\circ} 35^{\prime} \mathrm{N}, 39^{\circ} 44^{\prime} \mathrm{E}$, Amhara Region (formerly Shewa Province), coll. Negash Hanna, 22 Apr. 1970, NMU TRW 1970.11; 3 subadults, cws 16, 13.5, 13.5, 2 juv. cws 8.0, 7.5 mm, Amhara Region, Debre Marqos, east-central Ethiopia, Misraq Gojjam Zone, 2,446 m asl, $10^{\circ} 20^{\prime} \mathrm{N}, 37^{\circ} 43^{\prime} \mathrm{E}$, NHM 2011.1569-1573.

\section{Type material}

The type specimen of Thelphusa berardi Audouin, 1826, is lost (Capart, 1954). Consequently, a number of authors have used different specimens to illustrate this species. For example, Rathbun (1904) illustrated a 


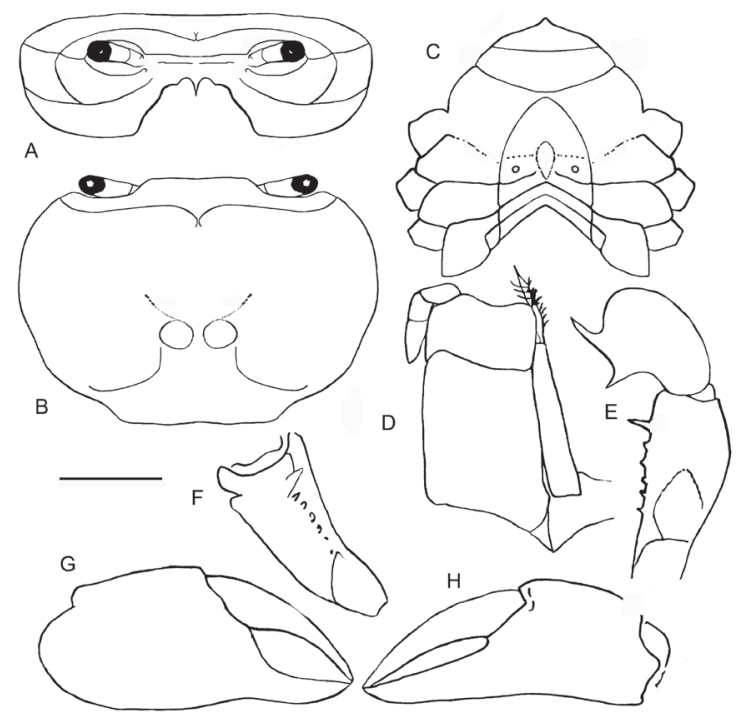

Fig. 6. Potamonautes ignestii (Parisi, 1923). Adult male, cw $33.5 \mathrm{~mm}$, from Amhara Region, Agew Awi Zone, Dangila, southwest of Lake Tana, Ethiopia (NMH 1927.4.6.1-2 /NMH ZOO 2011-381). (A) carapace frontal view; (B) dorsal view; (C) sternum ventral view; (D) left third maxilliped; (E) carpus and merus of cheliped dorsal view; $(\mathrm{F})$ merus of cheliped ventral view; $(\mathrm{G})$ right cheliped frontal view; $(\mathrm{H})$ left cheliped frontal view. Scale bar: $9.3 \mathrm{~mm}$ (A, B, C, E, F, G); $3.5 \mathrm{~mm}$ (D).

non-type adult male of Thelphusa berardi (cw 31, cl 20, fw $8.6 \mathrm{~mm}$ ) from the Nile River, and Capart (1954) illustrated the carapace and the G1 of a different nontype male collected in the Nile River by Jousseaume in 1887 (identified as P. berardi by Nobili (1906) and Bouvier (1917)). Bott (1955: pl. 23, fig. 1 a-d; fig. 53a-b) illustrated this species using a specimen from the Nile River from the SMF collection (SMF 1796, cw 30, cl 21 , ch 13, fw $8.5 \mathrm{~mm}$ ). In addition, Monod (1980) illustrated this species from a specimen from the Nile River from the MNHN collection, and Cumberlidge and Clark (2010a) described it from a specimen from the NHM collection. Although the absence of a type material has meant that specimens of this species have been described by numerous authors from different parts of its range, this has fortunately not been taxonomically problematic. This is because there has been little debate about the identification of $P$. berardi since its description in 1826 , and it has not generally been confused with other taxa. However, one exception to this were specimens from Mount Elgon, Uganda, now identified as $P$. williamsi Cumberlidge and Clark, 2010b, that were originally provisionally identified by Williams et al. (1964) as 'P. berardi' on the basis of their small body size and smooth carapace margins.

\section{Diagnosis}

Postfrontal crest incomplete, faint in the middle; exorbital, epibranchial teeth both small granules; anterolateral margin immediately behind epibranchial tooth smooth; ischium of third maxilliped smooth, lacking vertical suture; thoracic sternal suture $\mathrm{s} 3 / \mathrm{s} 4$ complete; dactylus of major cheliped strongly arched enclosing broad oval interspace when closed, two large teeth on fixed finger and two large teeth on moveable finger; first carpal tooth on carpus of cheliped large pointed, second carpal tooth weak, low, blunt; ventral margins of merus of pereiopod 1 both granulated; distal meral tooth large, pointed; terminal article of G1 slim, straight basally, curving outward in midsection, not widened in middle, tip curving upward. Small-sized species, adult size range from cw $23 \mathrm{~mm}$. For detailed descriptions, photographs, and illustrations of $P$. berardi see Capart (1954), Bott (1955), Monod (1980), Cumberlidge (2009), and Cumberlidge and Clark (2010a).

\section{Remarks}

The complete synonymy prior to 1954 is provided by Bott (1955). This was the first species to be reported from Ethiopia and was treated by Bott (1955) as a valid species in the subgenus $P$. (Rotundopotamonautes). While P. berardi is accepted as a valid species, the subgenus $P$. (Rotundopotamonautes) is likely paraphyletic and is not recognized here, an opinion that agrees with a number of other workers (Cumberlidge, 1997, 1998, 2009; Ng et al., 2008; Cumberlidge et al., 2009; Cumberlidge and Meyer, 2010).

\section{Ecology}

Potamonautes berardi is a common aquatic species found throughout the Nile river basin and its tributaries.

\section{Distribution}

Potamonautes berardi occurs in the major channels of the Nile and its tributaries and has a wide distribution in the Nile River basin in Egypt, Sudan, Ethiopia, Uganda, Tanzania, and Rwanda (Williams, 1968, 1976; Cumberlidge, 1997, 1998, 2009). See Cumberlidge and Clark (2010a) for a discussion of the distributional limits of $P$. berardi.

\section{Conservation status}

This species is assessed as least concern (LC) based on its relatively wide distribution (extent of occurrence 
$(\mathrm{EOO})>3$ million $\mathrm{km}^{2}$ ) and the relatively high number of localities and records of occurrence (21) from five countries (Cumberlidge et al., 2009; Table 1).

\section{Potamonautes holthuisi Cumberlidge and Meyer, 2010}

Fig. 7C, Tables 1-2

Potamonautes holthuisi Cumberlidge and Meyer, 2010: 179-188, figs. 1-4, table 1.

\section{Type material}

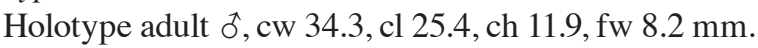
Southwestern Ethiopia, Nechisar National Park, Southern Nations, Nationalities, and Peoples Region (formerly Gamo Gofa Province), Bodessa River, tributary of the Sagan (= Segan) River, $05^{\circ} 49 \mathrm{~N}, 37^{\circ} 45 \mathrm{E}$, 1,829 m asl, coll. E.A. Means, 19 May-3 Jun. 1912 (USNM 82304 A).

\section{Diagnosis}

Carapace highly arched (ch/fw 1.2). Exorbital, epibranchial teeth reduced to granules, postfrontal crest faint in middle, well defined at lateral ends meeting epibranchial teeth; anterolateral margin granular. Ischium of third maxilliped lacking vertical groove. Sternal suture s3/s4 U-shaped, deep at edges, faint in middle, almost meeting sternoabdominal cavity. Inferior margins of merus of cheliped granular, distal meral tooth small, low; first carpal tooth medium-sized, pointed, second carpal tooth reduced to large granule. G1 terminal article slim, straight basally, mid-section curving gently outward at $60^{\circ}$ angle to longitudinal axis of gonopod, tip distinctly upturned.

\section{Remarks}

This species was described and illustrated in detail by Cumberlidge and Meyer (2010). Potamonautes holthuisi is a medium sized species that is adult at around cw $35 \mathrm{~mm}$, and this, together with the form of the G1 terminal article help to distinguish it from similar species (such as $P$. ignestii, $P$. kundudo and $P$. berardi) that lack teeth on the anterolateral margin (Table 2).

\section{Ecology}

Both of the two known localities for $P$. holthuisi lie in the Omo-Lake Turkana freshwater ecoregion that comprises Lakes Turkana (mostly in Kenya), Lakes Abaya and Chamo (in the northeastern portion of the Turkana ecoregion in Ethiopia), and the headwaters of the Omo River in southwestern Ethiopia (Thieme et al., 2005; Abell et al., 2008).

\section{Distribution}

Potamonautes holthuisi is known from two localities in the highlands of southwestern Ethiopia, in the Bodessa and Werka Rivers. The Bodessa River is a tributary of the Sagan (= Segan) River that flows into Lake Chamo, while the Werka River drains into Lake Abaya, just north of Lake Chamo (Cumberlidge and Meyer, 2010).

\section{Potamonautes ignestii (Parisi, 1923)}

Figs. 6, 7D, Tables 1-2

Potamon (Geothelphusa) ignestii Parisi, 1923: 332334, pl. 8, fig. 1.

Potamon ignestii - Chace, 1942: 213.

Potamonautes (Rotundopotamonautes) berardi ignestii - Bott, 1955: 289-290, pl. 23, figs. 2a-d.

Potamonautes ignestii - Cumberlidge, 1998: 200; Ng et al., 2008: 171; Cumberlidge et al., 2009: Appendix 1, 20; Cumberlidge, 2009: 548, 554, 557, table 1; Cumberlidge and Meyer, 2010: 180, 184, 187, table 1 .

\section{Type material}

Ethiopia: Adult ô holotype, cw 40.0, cl $28.5 \mathrm{~mm}$, Gondar near Lake Tana, MSNM nr. 2003. Three female paratypes (cws between 32 and $40 \mathrm{~mm}$ ) Gondar, Lake Tana, coll. U. Ignesti, 1921, MSNM.

\section{Material examined}

Ethiopia: Subadult ${ }^{\top}$, cw 29.5, cl .5, ch 12, fw $9.5 \mathrm{~mm}$, subadult $\widehat{\alpha}$, cw $26.5 \mathrm{~mm}$, subadult $q$, cw 32.9, Amhara Region, Caba River, Gondar, north of Lake Tana, $12^{\circ} 35^{\prime} \mathrm{N}, 37^{\circ} 28^{\prime} \mathrm{E}, \mathrm{ZSM} 1182 / 1$. Amhara Region, Caha River, Gondar, April, 1923, USNM 59366; adult ô, cw 33.5, cl 23.4, ch 14.1. fw $11.3 \mathrm{~mm}$, adult + , cw 32.5 mm, Amhara Region, Agew Awi Zone, Dangila, southwest of Lake Tana, $11^{\circ} 16^{\prime} \mathrm{N}, 36^{\circ} 50^{\prime} \mathrm{E}$, coll. Major Cheeseman, NMH 1927.4.6.1-2/NMH ZOO 2011-381.

\section{Diagnosis}

Carapace highly arched (ch/fw 1.3). Postfrontal crest complete, well defined, meeting anterolateral margin at epibranchial teeth; exorbital, epibranchial teeth both reduced to granules; anterolateral margin immediately behind epibranchial tooth smooth; ischium of third maxilliped smooth, lacking vertical suture; thoracic sternal suture $\mathrm{s} 3 / \mathrm{s} 4$ deep and complete; dactylus 

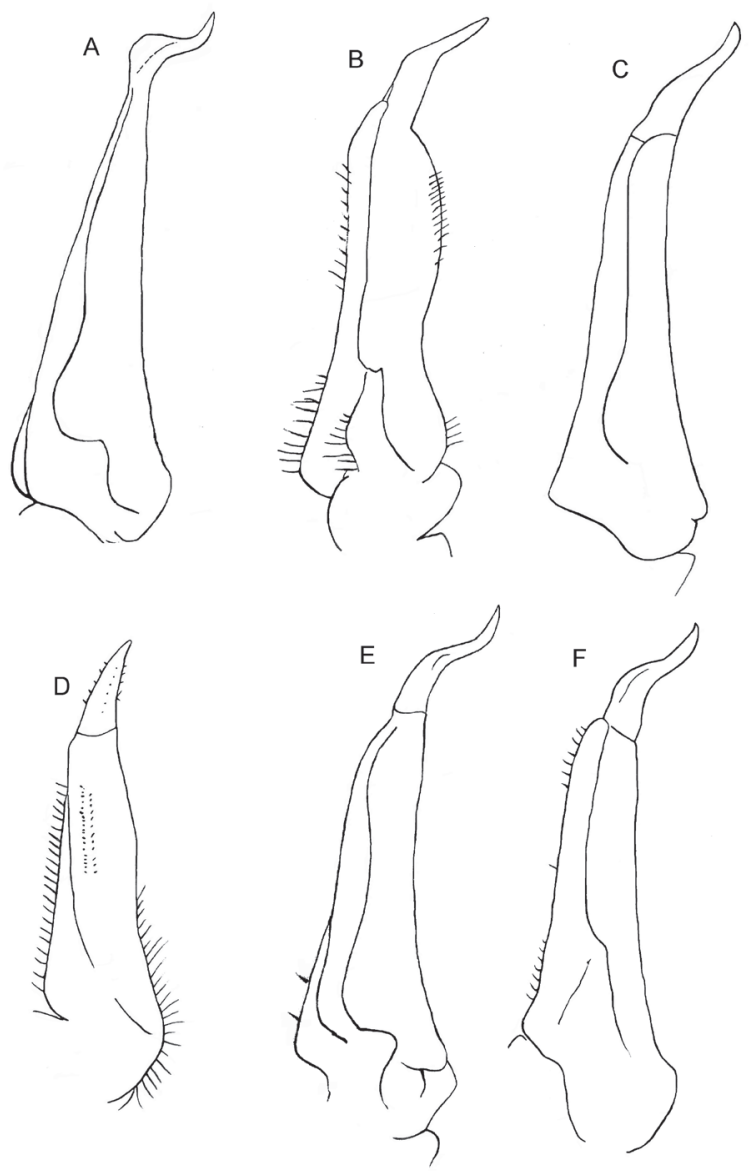

Fig. 7. Ventral view of the first gonopod of adult males of the six species of Potamonautes found in Ethiopia. (A) P. antheus; (B) P. berardi; (C) P. holthuisi; (D) P. ignestii; (E) P. kundudo; (F) P. niloticus. Scale bar: $14 \mathrm{~mm}$.

of major cheliped slightly arched enclosing long narrow interspace when closed; first carpal tooth on carpus of cheliped large, pointed, second carpal tooth weak, low, pointed; ventral margins of merus of pereiopod 1 both granulated; distal meral tooth large, pointed; terminal article of G1 straight basally mid-section curving sharply outward and distinctly widened, tip turned upward. Medium-sized species, adult at or above cw $35 \mathrm{~mm}$.

\section{Remarks}

The type material of Potamon (Geothelphusa) ignestii (museum nr. 2003) comprises one adult male (cw 40, cl $28.5 \mathrm{~mm}$ ) and three females (cws between 32 and 40 $\mathrm{mm}$ ) that were collected by U. Ignesti in 1921 from Gondar in the region of Lake Tana and deposited in the Museo civico di Storia naturale di Milano, Italy
(MSNM). The redescription given here is based on a non-type adult male (cw $33.5 \mathrm{~mm}$ ), from Amhara Region, Agew Awi Zone, Dangila, southwest of Lake Tana (NMH 1927.4.6.1-2/NMH ZOO 2011-381) (Fig. 6) that conforms closely to the published description of the type described by Parisi (1923) from Gondar near Lake Tana.

The Ethiopian taxon Potamon (Geothelphusa) neumanni (Hilgendorf) var. laetabilis, de Man, 1914, from Let Marefia $\left(9^{\circ} 38^{\prime} 0^{\prime \prime N}, 39^{\circ} 45^{\prime} 0^{\prime \prime} \mathrm{E}\right)$ 'Shoa' (= Sheba Province, now Oromia Region) resembles $P$. ignestii in some respects, but we are not confident that it is similar enough to $P$. ignestii to warrant it's inclusion in this species. Bott (1955) treated Potamon (G.) neumanni var. laetabilis as a junior synonym of Potamonautes didieri (Rathbun, 1904) from the D. R. Congo, but we consider that these two geographically separated taxa probably belong to two distinct species. This opinion has been provisionally accepted by several authors (Yeo et al., 2008; Ng et al., 2008, Cumberlidge et al., 2009).

Potamonautes ignestii is a medium sized species (adult at $\mathrm{cw} 35 \mathrm{~mm}$ ), with a strikingly-arched carapace, a G1 with a terminal article that curves sharply outward, with a distinctly widened mid-section and an upturned tip. These characters help to distinguish it from similar medium-sized species (such as P. holthuisi and P. kundudo), or smaller species (such as P. berardi) that lack a highly arched carapace and whose G1 terminal article has a slim (not widened) mid-section (Table 2).

Bott (1955) treated P. ignestii from Gondar near Lake Tana as the subspecies $P$. (R.) berardi ignestii, but this view is not in agreement with a number of other authors who all considered both P. berardi and $P$. ignestii to be valid species (Colosi, 1924; Balss, 1929, Chace, 1942; Ng et al., 2008; Cumberlidge et al., 2009; Cumberlidge, 2009; Cumberlidge and Meyer, 2010).

Bott (1955) also treated Potamon (Potamonautes) lindblomi Colosi, 1924, from Machako, Kenya as a junior synonym of P. ignestii (as Potamonautes (Rotundopotamonautes) berardi ignestii). Unfortunately, Bott (1955) added to the taxonomic confusion regarding the identity of $P$. ignestii when he illustrated $P$. ignestii (Bott, 1955, pl. XXIII, fig. 2a-d) with photographs of the lectotype of Potamon lindblomi Colosi, 1924 (SNHM 7691, cw 18.5, cl, 13.5, ch 8.0, fw $6.0 \mathrm{~mm}$ ) from Machako, southwest of Nairobi, Kenya. Bott's 1955 view that $P$. (R.) berardi ignestii was a senior synonym of $P$. lindblomi is not in agreement the opinions of a number of other authors who all treated $P$. ignestii and $P$. berardi 
as valid species (Colosi, 1924; Chace, 1942; Ng et al., 2008; Cumberlidge et al., 2009; Cumberlidge and Meyer, 2010). The type specimen of $P$. lindblomi was examined during the course of these studies by the first author who concluded that it should properly be treated as a valid species (P. lindblomi Colosi, 1924). Potamonautes lindblomi is distinguished from $P$. ignestii by the carapace height (which is flat in P. lindblomi but highly arched in $P$. ignestii), and by the ischium of the third maxilliped (which has a deep vertical suture in $P$. lindblomi but lacks a vertical suture in P. ignestii). In order to clarify the long-standing confusion regarding the identity of $P$. ignestii the characters of the gonopods are described and illustrated here for the first time based on an adult non-type specimen from near Gondar near Lake Tana that corresponds closely with the type described by Parisi (1923) from Gondar near Lake Tana.

Bott (1955) also included Potamon (Geothelphusa) didieri Rathbun, 1904 (as P. (Rotundopotamonautes) didieri) as part of the Ethiopian fauna because he accepted the opinion of Chace (1942) that P.didieri was from that country. However, it is doubtful that $P$. didieri is actually from Ethiopia. For example, the type locality of $P$. didieri is 'Le Kibali (embouchure) 1,015m asl, Mission du Bourg de Bozas, collected by L. Didier, 1903'. There is no evidence that this locality is in Ethiopia, and it is most likely the Kibali River in eastern D. R. Congo. In summary, P. didieri is here regarded as a valid species found in the D. R. Congo, and one that is not part of the Ethiopian freshwater crab fauna.

\section{Ecology}

No data available.

\section{Distribution}

Potamonautes ignestii is endemic to Ethiopia (Cumberlidge, 1997, 1998, 2009) and is known from two localities near Lake Tana, the source of the Nile in Ethiopia. These localities are both in the Amhara Region: the Caba (= Caha) River, Gondar, north of the lake, and Dangila, in the Agew Awi Zone southwest of the lake. This study adds new localities near Lake Tana from previously unpublished specimens that were collected between 1923 and 1927, which was the last time that this species was seen in the field.

\section{Conservation status}

Potamonautes ignestii is listed (IUCN, 2009) as vulnerable (VU, B1ab(i); D2) in view of its narrow distribution (its extent of occurrence is less than $20,000 \mathrm{~km}^{2}$ ) and the fact that it is known from less than five localities and has not been collected since 1927. It is also vulnerable to threats because it is not found in a protected area (Cumberlidge et al., 2009; Table 1).

\section{Potamonautes niloticus (H. Milne Edwards, 1837)}

Fig. 7F, Tables 1-2

Thelpheusa niloticus H. Milne Edwards, 1837: 12.

Potamon niloticus - Capart, 1954: 841, figs. 35, 16.

Potamonautes (Acanthothelphusa) niloticus - Bott, 1955: 260, pl. XIII, fig. 1a-c, fig. 30a-b; Monod, 1980: 382-383, pl. IV, fig. 22.

Potamonautes niloticus - Cumberlidge, 1997: 579; 1998: 202; 2009: 548-549, 551-557, fig. 1; Ng et al., 2008: 171; Cumberlidge et al., 2009: appendix 1, 20; Cumberlidge, 2009: 548, 551-557, table 1, fig. 1; Cumberlidge and Clark, 2010a: 1808-1812, fig. 1; Cumberlidge and Meyer, 2010: 184, 186, table 1.

\section{Type material}

The type specimen deposited in the Muséum national d'Histoire naturelle, Paris is a dried male, collected from Egypt by Rüppell in 1830 and is in poor condition (Capart, 1954). The diagnosis given by Cumberlidge and Clark (2010a) was based on a non-type adult male specimen collected from the Yala River, Kaimoisi, Kenya that conforms to the published description of the type.

\section{Material examined.}

Ethiopia: Baro River at Pingoperi, $26 \mathrm{~km}$ upstream from Gambela Region, coll. A.W.R. McCrae, 17 Jun. 1967, NMU TRW 1968.16.

\section{Diagnosis}

Postfrontal crest complete, distinct; epigastric, postorbital crests fused; postorbital crests extending laterally to meet anterolateral margins; exorbital, epibranchial teeth both strong, sharp; anterolateral margin immediately behind epibranchial tooth with row of distinct spines; thoracic sternal suture s3/s4 complete; dactylus of major cheliped strongly arched enclosing broad oval interspace when closed; first carpal tooth on carpus of cheliped large, pointed, second carpal tooth weak, low, blunt; ventral margins of merus of pereiopod 1 both granulated; distal meral tooth strong, pointed; terminal article of G1 straight basally, curved outward in mid-section, mid-section widened by thickened ventral lobe higher than dorsal 
lobe, upturned at tip. Large species, adult size range from cw 54 to $\mathrm{cw} 63 \mathrm{~mm}$.

\section{Remarks}

The complete synonymy prior to 1954 is provided by Bott (1955). That author assigned this species to the subgenus $P$. (Acanthothelphusa), but although the present study recognizes this as a valid species, the validity of the subgenus is not accepted, an opinion that is in accordance with other workers (Cumberlidge, 1997, 1998, 2009; Ng et al., 2008; Cumberlidge et al., 2009; Cumberlidge and Meyer, 2010).

\section{Distribution}

Potamonautes niloticus is a large and common species with a wide distribution which is known from more than 60 localities in six countries associated with the Nile River and its tributaries in Ethiopia, Egypt, Sudan, Southern Sudan, Uganda, Kenya, and Rwanda (Cumberlidge, 1997, 1998, 2009). Cumberlidge and Clark (2010a) reported that P. niloticus also occurs just outside the Afrotropical zoogeographical region in the Mediterranean subregion of the Palaearctic region in Egypt. The material included here from near Pingoperi in southwestern Ethiopia is from the Baro River which rises in the Ethiopian Highlands and flows west for 300 kilometres to join the Pibor and Sobat Rivers, which then drain into the White Nile.

\section{Ecology}

Potamonautes niloticus lives in a range of aquatic habitats including the major channels of the Nile itself and its lowland tributaries, small and large lakes associated with the river basin, as well as small clear fast-flowing mountain streams with rocky beds, and sluggish warm lowland streams with muddy bottoms (Bott, 1955; Williams et al., 1964; Cumberlidge, 1997, 1998, 2009; Cumberlidge and Clark, 2010a, b). This species is completely dependent on aquatic habitats and it never leaves the water whether it is found in streams, rivers, or lakes. The populations of $P$. niloticus are abundant enough in Lake Victoria to support small-scale local fisheries. In the southern parts of its range in Kenya and Uganda, $P$. niloticus serves as a host for the aquatic larvae of the biting blackfly, Simulium sp., which are the vectors of $\mathrm{On}$ chocerca volvulus, the parasite that causes river blindness in humans (Crosskey, 1990). There is no evidence that $P$. niloticus is associated with this disease in Ethiopia.

\section{Conservation status}

Potamonautes niloticus is listed (IUCN, 2009) as least concern (LC) in view of its wide distribution, estimated stable population size and abundance (it supports small-scale local fisheries in Lake Victoria in Uganda and Kenya), and the lack of known widespread longterm threats (Cumberlidge et al., 2009; Table 1).

\section{Biogeography}

Ethiopia occupies more than 1.1 million $\mathrm{km}^{2}$ of northeastern Africa and is bordered to the north by Eritrea, to the east by Djibouti and Somalia, to the west by Southern Sudan, and to the south by Kenya. Ethiopia is divided administratively into nine Regions and two chartered cities (Addis Ababa and Dire Dawa). Ethiopia is an ecologically diverse country with deserts along the eastern border, tropical forests in the south, and extensive Afromontane ecosystems in the north and southwest. The landscape of Ethiopia is dominated by a raised central plateau $(1,290$ to $3,000 \mathrm{~m}$ asl) and high mountains (up to 4,500 $\mathrm{m}$ asl), and is divided into two highland blocks by the Great Rift Valley that runs southwest to northeast. The northern highland block of the central plateau slopes northwestward down to the lowlands of Southern Sudan and is drained by a number of rivers (Baro, Tekezé, Abay, Sobat, and Blue Nile) that carry the vast majority (85\%) of Ethiopia's fresh water. The southern highland block of the plateau slopes southeast to the plains of Somalia and is drained by the Wabi Shebele, Genale, and Jubba rivers that flow through lowlands, steppes, and semi-desert. Other notable Ethiopian rivers are the Awash, which flow to the saline lacustrine district along the border with Djibouti, and the Omo River, which drains southwest into the closed basin of Lake Turkana.

Two Ethiopian species (P. niloticus and P. berardi) are common in the Nile River basin and each has a wide distribution well beyond the borders of the country. For example, $P$. niloticus inhabits the lower reaches of the Blue Nile in the Gambela Region of western Ethiopia, while P. berardi is found throughout the Nile basin and is widely distributed in the highland areas in the Amhara, Southern Nations, Nationalities, and Peoples, and Oromia Regions. Two of the four endemic species of Ethiopian freshwater crabs, $P$. antheus and $P$. ignestii, live in the rivers draining the highlands of western Ethiopia. Potamonautes antheus is found in the Oromia Region, and $P$. 
ignestii is found in the Amhara Region in the Lake Tana catchment area that includes the source of the Blue Nile. The other two endemic species, P. kundu$d o$ and $P$. holthuisi, each has a narrow distribution, the former from a cave in eastern Ethiopia, and the latter from two localities in the Omo River and its tributaries draining the southwestern Ethiopian highlands (in the Oromia and Southern Nations, Nationalities, and Peoples Regions) that flow southwest into Lake Chew Bahir (Cumberlidge and Meyer, 2010). It is likely that other species will be discovered in Ethiopia when exploration improves.

\section{Acknowledgements}

We thank Marco Virago and Danilo Baratelli for collecting and donating the material used in this study. We are also grateful to Karen Sindemark (SMNH) for her kind hospitality during a visit to the museum by the first author. The Peter White Scholar Award (NMU) is acknowledged for its support for the first author, and we are grateful to Phil Crabb (NHM Photography Unit) for taking the photographs reproduced in Figs 1 and 2. Finally, we are grateful for the helpful comments provided by two anonymous reviewers and the editors.

\section{References}

Abell R, Thieme ML, Revenga C, Bryer M, Kottelat M, Bogutskaya N, Coad B, Mandrak N, Balderas SC, Bussing W, Stiassny MJL, Skelton PA, Allen GR, Unmack P, Naseka A, Ng R, Sindorf N, Robertson J, Armijo E, Higgins JV, Heibel TJ, Wikramanayake E, Olson D, López HL, Reis RE, Lundberg JG, Pérez MHS, Petry P. 2008. Freshwater ecoregions of the world: A new map of biogeographic units for freshwater biodiversity conservation. BioScience 58: 403-414.

Audouin V. 1826. Explication sommaire des planches de Crustacés de l'Égypte et de la Syrie, publiées par Jules-César Savigny, Membre de l'Institut; offrant un exposé des caractères naturels des genres, avec la distinction des espèces. Animaux invertébrés. In: J.-C. Savigny, Description de l'Égypte ou receuil des observations et des recherches qui ont été faites en Égypte pendant l'expédition de l'armée française, publié par les orders de sa Majesté l'Empereur Napoléon le Grand. Histoire Naturelle 1(4): 77-98. Paris: Imperiale.

Balss H. 1929. Crustacea V. Potamonidae. In: Monod Th, Contributions à l'étude de la faune du Cameroun. Faune des Colonies françaises Paris 3: 115-129.

Bott R. 1955. Die Süßwasserkrabben von Afrika (Crust., Decap.) und ihre Stammesgeschichte. Annales du Musée du Congo belge, (Tervuren, Belgique) C-Zoologie (3,3), 3: 209352.

Bott R. 1970. Betrachtungen über die Entwicklungsgeschichte und Verbreitung der Süßwasser-Krabben nach der Sammlung des Naturhistorischen Museums in Genf/ Schweiz. Revue Suisse de Zoologie 77: 327-344.
Bouvier E-L. 1917. Sur la classification des Eupotamonea, Crabes d'eau douce de la famille des Potamonides. Comptes Rendus de l'Académie des Sciences 165: 615-621.

Capart A. 1954. Révision des Types des espèces de Potamonidae de l'Afrique tropicale conservées au Muséum national d'Histoire naturelle de Paris. Volume jubilaire Victor Van Straelen, Directeur de l'Institut royal des Sciences naturelles de Belgique 1925-1934 II: 819-847.

Chace FA. 1942. II. Decapod Crustacea. In: Scientific results of the fourth expedition to forested areas in eastern Africa. Bulletin of the Museum of Comparative Zoology, Harvard College 91(3): 185-233.

Corace RG, Cumberlidge N, Garms R. 2001. A new species of freshwater crab from Rukwanzi, East Africa. Proceedings of the Biological Society of Washington 114: 178-187.

Colosi G. 1920. I Potamonidi conservati nel R. Museo zoologico di Torino. Bollettino dei Musei di Zoologia ed Anatomia comparata della R. Universitá di Torino 35: 1-39.

Colosi G. 1924. Potamonidés africains du Muséum de Stockholm. Arkiv für Zoologie 16: 1-24.

Crosskey RW. 1990. The natural history of blackflies. Wiley, Chichester, UK. Pp. 1-711.

Cumberlidge N. 1997. The African and Madagascan freshwater crabs in the Museum of Natural History, Vienna (Crustacea: Decapoda: Brachyura: Potamoidea). Annalen des Naturhistorischen Museums in Wien 99B: 571-589.

Cumberlidge N. 1998. The African and Madagascan freshwater crabs in the Zoologische Staatssammlung, Munich (Crustacea: Decapoda: Brachyura: Potamoidea). Spixiana 3: 193-214.

Cumberlidge N. 1999. The freshwater crabs of West Africa, family Potamonautidae. Collection Faune et Flore Tropicales 36. Paris: Orstom.

Cumberlidge N. 2009. Freshwater crabs and shrimps (Crustacea: Decapoda) of the Nile Basin. In: Dumont HJ, ed., The Nile. Origin, environments, limnology and human use. Monographiae Biologicae 89: 547-561.

Cumberlidge N, Clark PF. 2010a. Two new species of freshwater crabs from Mount Elgon, East Africa (Brachyura: Potamoidea: Potamonautidae) and a re-diagnosis of Potamonautes niloticus (H. Milne Edwards, 1837) with notes on their natural history and onchocerciasis. Journal of Natural History 44: 1807-1829.

Cumberlidge N, Clark PF. 2010b. A redescription of Potamonautes loveni (Colosi, 1924), a medically important freshwater crab from western Kenya and eastern Uganda, East Africa (Brachyura: Potamoidea: Potamonautidae). In: Castro P, Davie PJF, Ng PKL and Richer de Forges B (eds) Studies on Brachyura: A homage to Danièle Guinot. Crustaceana Monographs 11: 61-74. Leiden: Brill.

Cumberlidge N, Meyer KS. 2010. A new species of Potamonautes MacLeay, 1838, from southwestern Ethiopia (Decapoda, Brachyura, Potamonautidae). In: Fransen CHJM, De Grave S, Ng PKL, eds, Studies on Malacostraca: Lipke Bijdeley Holthuis Memorial Volume. Crustaceana Monographs 14: 179-190. Leiden: Brill.

Cumberlidge N, Ng PKL, Yeo DCJ, Magalhaes C, Campos MR, Alvarez F, Naruse T, Daniels SR, Esser LJ, Attipoe FYK, Clotilde-Ba FL, Darwall W, McIvor A, Ram M, Collen B. 2009. Freshwater crabs and the biodiversity crisis: importance, threats, status, and conservation challenges. Biological Conservation 142: 1665-1673. 
IUCN 2009. IUCN Red List of Threatened Species, ver. 2009.2. Available from http://www.iucnredlist.org [visited 24 November 2012].

Lanchester WF. 1900. On a collection of Crustaceans made at Singapore and Malacca. Part 1. Crustacea Brachyura. Proceedings of the Zoological Society of London 1900: 717-770.

MacLeay WS. 1838. Brachyurous Decapod Crustacea. Illustrations of the Zoology of South Africa 5; being a Portion of the Objects of Natural History Chiefly Collected during an Expedition into the Interior of South Africa, under the Direction of Dr. Andrew Smith, in the Years 1834, 1835, and 1836; Fitted Out by "The Cape of Good Hope Association for Exploring Central Africa." In: Smith A Illustrations of the Zoology of South Africa; Consisting Chiefly of Figures and Descriptions of the Objects of Natural History Collected During an Expedition into the Interior of South Africa, in the Years 1834, 1835, and 1836; Fitted Out by "The Cape of Good Hope Association for Exploring Central Africa." (Invertebrates) (1849): 1-75. London: Smith, Elder and Co. [for dates of publication see Waterhouse 1880: 489-491]

Man JG de. 1914. Note sur quelques Crustaces decapodes brachyures. Annali del Museo Civico di Storia Naturale di Genova (3) 6: 122-138.

Milne Edwards H. 1837. Histoires naturelles des Crustacés, comprenant l'anatomie, la physiologie et la classification de ces animaux 2: 1-532. Paris: Librairie encyclopédique de Roret.

Monod T. 1980. Décapodes. In: Durand J-R, Leveque C (eds) Flore et Faune Aquatiques de l'Afrique Sahelo-Soudanienne. ORSTOM, Paris, I.D. T. 44: 369-389.

Ng PKL. 1989. The identity of the cavernicolous freshwater crab Potamon (Thelphusa) bidiense Lanchester, 1900 (Crustacea: Decapoda: Brachyura: Gecarcinucidae) from Sarawak, Borneo, with description of a new genus. Raffles Bulletin of Zoology 37: 63-72.

Ng PKL, Guinot D, Davie P. 2008. Systema Brachyuorum: Part I. An annotated checklist of extant Brachyuran crabs of the world. Raffles Bulletin of Zoology, supplement 17: 1-286.
Nobili G. 1906. Spedizione al Ruwenzori di S.A.R. Luigi Amedeo di Savoia Duca degli Abruzzi. 9. Crostacei. Bollettino dei Musei di Zoologia e Anatomia Comparata, Torino 21(544): 1-2.

Parisi B. 1923. Un nouvo Potamonide dell'Abbissinia. Atti della Società italiana di scienze naturali e del Museo civico di storia naturale di Milano 61: 332-334.

Rathbun MJ. 1904. Les Crabes d'Eau Douce (Potamonidae). Nouvelles Archives du Muséum d'Histoire naturelle (Paris) 6: 225-312.

Thieme ML, Abell RA, Stiassny MJL, Skelton PA, Lehner B, Teugels GG, Dinerstein E, Toham AK, Burgess N, Olson D. 2005. Freshwater ecoregions of Africa and Madagascar: A conservation assessment: i-xxi, 1-462. Washington: Island Press.

Williams TR, Hynes HBN, Kershaw WE. 1964. Freshwater crabs and Simulium neavei in East Africa II. Further observations made during a second visit to East Africa in February-April 1962. Annals of Tropical Medicine and Parasitology 58: 159-168.

Williams TR. 1968. The taxonomy of the East African river crabs and their association with the Simulium neavei complex. Transactions of the Royal Society of Tropical Medicine and Hygiene 62: 29-34.

Williams TR. 1976. Freshwater crabs of the Nile system. Pp. 353-384 in: Rzóska J, ed., The Nile Biology of an Ancient River. The Hague: Junk.

Yeo DCJ, Ng PKL, Cumberlidge N, Magalhaes C, Daniels SR, Campos M. 2008. A global assessment of freshwater crab diversity (Crustacea: Decapoda: Brachyura). In: Balian EV, Lévequè C, Segers H, Martens M, eds, Freshwater Animal Diversity Assessment. Hydrobiologia 595: 275-286.

Received: 4 April 2012

Revised and accepted: 2 November 2012

Published online: 14 December 2012

Guest editor: C.H.J.M. Fransen 


\section{Appendix}

Key to the Ethiopian species of Potamonautes

All Ethiopian species of freshwater crabs lack a vertical groove on the ischium of the third maxilliped, but posses (except for P. niloticus) exorbital and epibranchial teeth that are both either reduced to a granule or not visible at all, and an anterolateral margin that is either smooth or granular.

1. Anterolateral margin toothed P. niloticus

2. Anterolateral margin granular or smooth 3

3. Adult body size large (cw $65 \mathrm{~mm})$ P. antheus

4. Adult body size medium or small (cw $22-40 \mathrm{~mm}$ ) 5

5. Postfrontal crest distinct, complete P. ignestii

6. Postfrontal crest faint, incomplete 7

7. Anterolateral margin granular, carapace sidewall vertical suture not meeting anterolateral margin . P. kundudo

8. Anterolateral margin smooth, carapace sidewall vertical suture meeting anterolateral margin

9. G1 terminal article tip upturned, adult body size medium (cw $35 \mathrm{~mm}$ ) P. holthuisi

10. G1 terminal article tip straight, adult body size small (cw $22-31 \mathrm{~mm}$ ) P. berardi 
